\title{
The Effect of Cooperative Learning Model of Teams Games Tournament Type in Salt Hydrolysis Material on Student's Motivation and Learning Outcomes at Class XI SMAN 5 Palu
}

\author{
Minarni Rama Jura \\ Universitas Tadulako \\ Palu, Indonesia \\ minarni.ramajura@gmail.com \\ Mery Napitupulu \\ Universitas Tadulako \\ Palu, Indonesia \\ merytn@gmail.com
}

\author{
I Putu Hendra Budi \\ Universitas Tadulako \\ Palu, Indonesia \\ iputuhendrabudi@gmail.com
}

\begin{abstract}
The study was aimed to investigate the effect of cooperative learning model of teams games tournament (TGT) type in salt hydrolysis material on student's motivation and learning outcomes at class XI SMAN 5 Palu. This study was a quasi-experimental with non randomized pretest-posttest control group design. The 32 students of class XI-2 had used as an experimental class and 31 students of class XI-1 had used as a control class. The test of student's learning outcomes data was conducted using the two tailed t-test statistical analysis with the prerequisite test: test for normality and homogeneity of the test given after learning (post-test). The data obtained, average of the experiment class value was 69,00 with standard deviation is 10.66 and the control class was 64,71 with standard deviation is 11,38 . The results of test of hypotheses by the statistical obtained that $t_{\text {table }} \leq t_{\text {calculation }} \leq+t_{\text {table }}\left(t_{\text {calculation }}=2,16\right.$ and $\left.t_{\text {table }}=1,67\right)$ with a significance level $\alpha=0.05$ and 61 for the degrees of freedom, therefore the $H_{0}$ was rejected and $H_{a}$ was accepted. The student's motivation was analyzed using a descriptive statistical analysis on the questionnaire of student's learning motivation. The results obtained that the experimental class was on a strongly agree attitude with the positive category of $87.07 \%$ and the control class was on a hesitate attitude with the positive category of $63.67 \%$. The conclusion which obtained, there is a significant effect of cooperative learning model of teams games tournament type in salt hydrolysis material on student's motivation and learning outcomes at class XI SMAN 5 Palu.
\end{abstract}

Keywords - teams games tournament; motivation; learning outcome; salt hydrolysis

\section{INTRODUCTION}

One of the priorities of Curriculum 2013 for chemistry lessons are student-centered learning. Researchers are particularly interested in Curriculum 2013, which prioritizes student's activity in learning. Students will be given a role that is more free to be creative and express themselves in learning then learning is expected to be more meaningful. This should make teachers more creative in selecting and developing learning materials that will be delivered to students [1]. The researcher focused on trying to apply cooperative learning model of teams games tournament type on chemical materials with fun game base and also competitive. Application of learning model of teams games tournament, is expected to improve the understanding of each student's concept, because the characteristics of this learning model is competitive, namely the presence of a tournament or a kind of academic competition among student groups.

The implementation of this model is expected to improve students skills in problems solving that related to the learning materials. "Education is central to the achievement of scientific literacy" [2]. One of the ideal learning model is applied to overcome these problems is a cooperative learning model of team tournaments games type as a learning model recreational, requires all students to be active in the learning process, increasing the activity of students, and to train the students responsible and cooperate. In this model, students played games with the members of the other group to earn additional points for their team score [3]. Students will compete to test their skills in problem solving that related to the material which has being studied. This will spur students to strive to master the material that has been studied in order to provide additional value to the group. The term cooperative means to do something together to help each other as a group or a team.

The research was intended to determine the differences effect of cooperative learning model of TGT on student's motivation and earning outcomes. TGT has a high motivation dynamics, but it also has the dynamics of excitement that occurs due to the use of the game [4]. Chemical materials selected to apply the learning model of TGT in this study is the salt hydrolysis. Salt hydrolysis is one of the chemical 
material that outlines the concepts and calculations at once, making it suitable to be used as teaching material in the study.

\section{METHOD}

This study was an experimental, which apply the cooperative learning model of TGT in salt hydrolisis material in the experiment class and examples of non-teaching model examples in control class [5]. This research was conducted in three steps: preparation step, implementation step, and final step which is intended below:

\section{A. Preparation step}

The preparation step including: 1) observation the place of the study, 2) determine the population and research sample. 3) designing the lesson plan with cooperative learning model of teams games tournament for the experiment class and examples of non-teaching model examples for the control class including a lesson plan with the allocation of time $4 \times 45$ minutes for all meetings. 4) developing motivation questionnaire and made the initial test questions (multiple choice) to obtain initial information about student's abilities. 5) preparing an evaluation tool to measure mastery of the subject matter and create questions for quiz tournament.

\section{B. Implementation step}

The implementation step was conducted to give motivation questionnaire and preliminary tests before starting the lessons in the experimental class and control class, learning activities in accordance with the learning scenarios that were prepared in the experimental class and control class. Applied experimental class cooperative learning model-based teams tournament quiz games, while the control class applied examples of non-teaching model examples. The last step motivation questionnaire administration as well as the final test as a data motivation and student learning outcomes.

\section{Final step}

At this step the data was collected, processed and analyzed which are all the data obtained during the implementation step and up to result report.

\section{DATA ANALYSIS TECHNIQUE}

Descriptive statistics were conducted to describe the study variables obtained through the measurement results. The description of the achievement of each variable is determining the value relationship pretest and posttest in the experiment class and control class using the $\mathrm{N}$-gain test.

Inferential statistical analysis was conducted to test the hypotheses and make generalizations. Before the test of the hypothesis, first tested the pre-requisite of research data, the normality and homogeneity test.

\section{RESUlT AND DISCUSSION}

This type of research is quasi experiment consisted of the experimental group (given treatment with cooperative learning model teams tournament games) and the control group (given treatment with learning model Examples of non-example). Description of the data obtained is strudent's motivation and learning outcomes in the experiment class (XI-2) as well as the control class (XI-1).

\section{A. Student Motivation}

Based on the research, data obtained experimental class students' learning motivation and control classes are presented in Tables I and II.

TABLE I. DATA RESUlTS OF EXPERIMENTAL ClASS STUDENT MOTIVATION

\begin{tabular}{cccccc}
\hline No & Indicator & Average & $\%$ & Demeanor & Category \\
\hline 1. & Attention & 4,39 & 87,87 & Strongly agree & Positive \\
2. & Attraction & 4,24 & 84,75 & Agree & Positive \\
3. $\quad$ liveliness & 4,35 & 87 & Strongly agree & Positive \\
4. & Satisfaction & 4,38 & 87,75 & Strongly agree & Positive \\
5. & conviction & 4,41 & 88,25 & Strongly agree & Positive \\
\hline $\begin{array}{l}\text { The } \\
\text { average }\end{array}$ & 4,35 & 87,07 & Strongly agree & Positive \\
\hline
\end{tabular}

TABLE II.

$$
\text { Data Results CONTROl Class Student Motivation }
$$

\begin{tabular}{clcccc}
\hline No & Indicator & Average & $\%$ & Demeanor & Category \\
\hline 1. & Attention & 3,29 & 65,87 & Hesitate & Positive \\
2. & Attraction & 3,25 & 65 & Hesitate & Positive \\
3. $\quad$ liveliness & 3,19 & 63,87 & Hesitate & Positive \\
4. & Satisfaction & 3,1 & 62 & Hesitate & Positive \\
5. & conviction & 3,08 & 61,62 & Hesitate & Positive \\
\hline $\begin{array}{l}\text { The } \\
\text { average }\end{array}$ & number and & 3,18 & 63,67 & Hesitate & Positive \\
\hline
\end{tabular}

Based on the results of descriptive analysis of level criteria or categories of student's motivation toward learning model application of TGT are in attitude agreed with the positive category is $87.07 \%$. The level of student's motivation toward learning model application examples of non-example is the hesitant attitude to the positive category is $63.63 \%$. Based on the percentage results, it can be said that the learning model application of TGT influence the students' motivation. The success of the learning process is the main thing that is coveted in carrying out education in schools [6].

Indicators attention to the experimental class and control class entered in the positive category. Learning is a complex mental phenomenon in which motivation is one of the key variables [7]. Experimental class giving attention very amenable attitude towards learning model teams tournament 
games, while giving control class hesitant attitude towards learning model examples of non-example. Based on these data it is known that the learning model of TGT can make students more focus onto lesson materials and tasks, as well as trying to present on time. Students tend to feel loss if you have to skip one task, because it can make them as lagging behind in the classroom. Different percentages shown in the control class. Learning model examples of non-example still makes them hesitant in giving attention to the materials and tasks, as well as disciplined with time.

Indicators of interest in the experimental class and control class showed a positive category but differ in the terms of attitude. The experiment class showed agree gesture, while the control class still showed hesitant attitude. The percentage level indicates that the using of TGT model on learning can help students of SMAN 5 Palu easier to understand the subject matter, can explore a broader knowledge, learning becomes fun and have compatibility learning method with the material being taught. The data shows the level of interest of students in learning by using learning model TGT higher than nonteaching model examples.

Indicators show the liveliness of spirit and liveliness ask students currently studying in the classroom. Both the experimental class and control class, they still get in on the positive category. The percentage data indicate that learning using TGT learning model can foster the seriousness of the students in the learning process, trying to improve understanding or concept that is less clear, and has a passion learn to define the course. However, the control class still provide hesitant attitude towards the activity indicator.

Satisfaction indicators show student satisfaction in learning with specific learning model. Second grade samples showed the percentage of satisfaction in the positive category. Experimental class showed very amenable attitude towards teams tournament games learning model, while the control group showed hesitant attitude towards examples of nonexample learning model. The data indicate that the percentage of the satisfaction of learning using TGT learning model can give satisfaction to the students to learn, to respect their opinions, and create a sense of brotherhood among friends.

Confidence indicator shows the confidence of students to the material that has been learned and felt ready to accept new material. Second grade samples showed levels of confidence in the positive category. Experimental class expressing strongly agreed that the TGT model can help students understand the lesson well, gained a lot of knowledge, it is easy to complete the task, get better performance and confident to face the exam. Unlike the experimental class, control class instead indicate hesitant attitude towards examples of non-example learning model. This means TGT learning model can influenced the confidence level of student learning in SMAN 5 Palu.

Overall the TGT learning model given the percentage of student motivation SMAN 5 Palu are good in all indicators. It is not independent of the style and attractive learning environment and be able to bring the atmosphere of playing while learning in the classroom. Changes motivation to learn is starting to look at the second meeting in the experimental class. Students of XI-2 class were given treatment this model is ready to learn at their own group even before the lesson begins. The atmosphere will certainly bring a comfortable feeling when learning from both teachers and students. It is also not free from saturation factor for students who have studied the examples of non-teaching model examples.

Classes are given treatment study model examples are examples of non-sampling control class. In general, this model was conducted with PowerPoint presentation help. Teachers convey the material through the PowerPoint media, and students were asked to provide questions regarding the material that has not been understood or identified issues. The cooperative learning model so that students can learn while interacting with the group. Based on data obtained from a questionnaire, provide control class hesitant attitude to all indicators of motivation to learn. It is more influenced by the saturation of the students learn to use a monotonous learning model in a long time. Saturation of the five indicators of students have an impact on the learning motivation.

If the terms of implementation, both actual TGT learning model as well as examples of non-example is an ideal learning model which applied in the salt hydrolysis material. It will be seen from the average difference in learning outcomes indicated by the second grade in the following discussion. However, the using of model examples of non-example much often (conventional) lead to saturation thus affecting the students' motivation. Chemistry is one of the most important branches of science and has been considered as a difficult subject for students with a chemistry teacher, researcher, and educator. Of course, chemistry is one of the most important branches of science and has been regarded as a difficult, a subject for young students by chemistry teachers, researchers, and educators [8]. Master is required to always innovate in the classroom. Creative teacher in teaching will present a fun learning environment in the classroom. Thus, students will not feel bored in the classroom and can keep learning motivation. Motivation to learn can arise due to intrinsic factors, such as desires and wishes success and encouragement of learning needs, expectations of the ideals. Whereas extrinsic factor is the existence of the award, a conducive learning environment, and engaging learning activities.

\section{B. Student learning outcomes}

Based on the research, data obtained experimental class student learning outcomes and control classes are presented in

TABLE III. STUDENT RESULTS ClASS COMPARISON EXPERIMENT AND
CONTROL

\begin{tabular}{|l|c|c|}
\hline \multirow{2}{*}{\multicolumn{1}{|c|}{ commentary }} & \multicolumn{2}{|c|}{ Postest } \\
\cline { 2 - 3 } & experimental class & control class \\
\hline Samples & 32 & 31 \\
\hline The lowest value & 45 & 45 \\
\hline The highest score & 85 & 85 \\
\hline The average score & 69,00 & 64,71 \\
\hline Deviation standard & 10,66 & \begin{tabular}{c}
11,38 \\
\hline
\end{tabular}
\end{tabular}


Based on the results obtained after the initial test and final test in Table III, obtained descriptive data for testing the $\mathrm{N}$ gain. Collection techniques this data by conducting a post-test at the end of the lesson . N-gain testing conducted to analyze the data in ways that describe or depict the data that has been collected based on the achievement of each of the variables in relation to the value of pretest and posttest students in experimental class and control class.

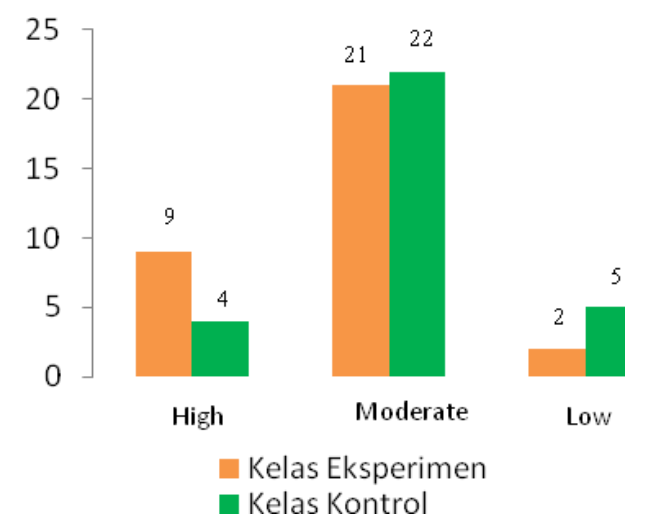

Fig.1. Tests N-gain graph Students In Class And Class Control Experiment

Based on the data shown in Fig. 1, shows that the number of students who have a high value for the category of the experimental class more than the control class. The implementation of cooperative learning model of TGT is quite a good result. Group category was showing that the number of students who value control class study results are in that category more than the experimental class. Class difference ahead only control one person. Low category data showing the number of experimental class students who have learned the value of that category is less than the number of control class. Therefore, the simple conclusion can be drawn that the application of cooperative learning model TGT shows the results of the evaluation study were better than cooperative learning model example non-example.

Student learning outcome data obtained from the two samples were normally distributed and homogeneous class, therefore the data is qualified to use parametric statistical hypothesis test. Based on this hypothesis that there are differences in the effect of cooperative learning model type TGT against learning outcomes of students in class XI SMAN 5 MIPA on material salt hydrolysis. Then the hypothesis testing was conducted by t-test two parties.
The $\mathrm{t}$ value $(0.95)$ with $\mathrm{dk}=61$ from the list of distribution is 2.00. Testing criteria is if -ttabel $\neg$ ttable $\leq \mathrm{t} \leq+(1-\alpha)$, (n1 $+\mathrm{n} 2-2$ ) received $\mathrm{H} 0$ and $\mathrm{Ha}$ rejected. According to results obtained $-2.00<2.16\rangle+2.00$ clear rejections of $\mathrm{H} 0$ is in the region so that $\mathrm{HO}$ is rejected and $\mathrm{Ha}$ accepted. Thus, it can be concluded that there are differences in the effect of cooperative learning model TGT against the results of studying chemistry class XI student of SMAN 5 Palu on hydrolysis where the TGT model can improve student academic achievement and attitude toward the subject matter as indicates by the previous study that TGT enhances students' academic achievement and attitudes towards the subject matter

Based on the data shown in the processing of descriptive and inferential statistics, it would seem that there are differences in the effect of cooperative learning model TGT. The average value of $\mathrm{N}$-gain obtained by each student treated tournament games teams learning models look taller than students who are given treatment study model examples of non-example. The learning model-type TGT will encourage students to be active in learning and practicing to solve problems. The principle of TGT is the students will learn while racing with other groups to get points. This technique works on the principle of a weekly TGT in the form of games, i.e. an academic spelling tournament, with learners competing against the members of other teams to earn team points [9]. Their game is wrapped in a competition will trigger the consciousness to know the extent of their achievement on the material. In short this model will encourage them to continue to practice solving problems and issues.

The effectiveness of learning is not only seen from the results of student learning but also emphasized the effectiveness of learning at the level of teacher's ability to manage the learning and mastery level of learning strategies and teachers against concordance rate of time spent during the process [10]. The quality of education provided to students is very dependent on what teachers do in the classroom. In addition, the effectiveness of learning can also be measured by looking at the interest or motivation of learners towards learning activities so that students are actively involved in the learning process [11]. Motivation needed in education in order to improve student learning outcomes. Students who have strong motivation, will have lots of energy for learning activities. Motivation will encourage students to learn with sincerity and makes learning more meaningful.

\section{CONCLUSIONS}

Based on the research analysis data results, it concluded there is a significant effect of cooperative learning model type teams games tournament on the students chemistry results of class XI MIPA SMA Negeri 5 Palu on salt hydrolysis material in terms of the average score of each class postes, namely experimental class 69.00 and control clas $=64,71$. It is also proved by the analysis of statistical data of t-two tailed test obtained -ttabel $\neg \leq$ tcount + ttable with significance level $\alpha=$ 0.05 and degrees of freedom 61. Based on the results obtained $-2.00\langle 2.16\rangle+2,00$ is clearly on the $\mathrm{H} 0$ rejection area, therefore $\mathrm{H} 0$ was rejected and Ha was accepted. 


\section{REFERENCES}

[1] D. M. Tyasning, . Haryono, and N. D. Nurhayati, "Penerapan Model Pembelajaran Tgt (Teams Games Tournaments) Dilengkapi Lks Untuk Meningkatkan Aktivitas Dan Hasil Belajar Materi Minyak Bumi Pada Siswa Kelas X-4 Sma Batik 1 Surakarta Tahun Pelajaran 2011/ 2012," J. Pendidik. Kim., vol. 1, no. 1, pp. 26-33, 2012.

[2] A. Hofstein and R. M. Naaman, "The laboratory in science education: the state of the art," Chem. Educ. Res. Pract., vol. 8, no. 2, p. 105, 2007.

[3] Trianto, Mendesain model pembelajaran inovatif progresif, 1st ed. Jakarta: Kencana, 2010.

[4] H. Purwati, "Keefektifan Pembelajaran Matematika Berbasis Penerapan Tgt Berbantuan Animasi Grafis Pada Materi Pecahan Kelas Iv," Aksioma, vol. 1, no. 2/September, 2012.

[5] R. Oktaviani, M. Sapti, and P. Nugraheni, "EKSPERIMENTASI MODEL PEMBELAJARAN KOOPERATIF DITINJAU DARI MOTIVASI BELAJAR SISWA KELAS VIII SMP NEGERI 2 BULUSPESANTREN," Semin. Nas. Mat. dan Pendidik. Mat. FMIPA UNY, no. November, pp. 978-979, 2012.

[6] L. Fajri and K. Martini, "Upaya peningkatan proses dan hasil belajar kimia materi koloid melalui pembelajaran kooperatif tipe TGT (Teams Games Tournament) dilengkapi dengan teka-teki," J. Pendidik. Kim., vol. 1, no. 1, pp. 89-96, 2012.

[7] W. N. Apurba L. Koner, "r P Fo r R w On ly," Int. J. Prod. Res., no. september, pp. 1-36, 2010.

[8] H. Ozmen, "Some Student Misconceptions in Chemistry :," vol. 13, no. $2,2004$.

[9] M. van Wyk, "The Effects of Teams-Games-Tournaments on Achievement, Retention, and Attitudes of Economics Education Students," J. Soc. Sci., vol. 26, no. 3, pp. 183-193, 2011.

[10] Effandi Zakaria and Zanaton Iksan, "Promoting cooperative learning in science and mathematics education: A Malaysian perspective," Eurasia J. Math. Sci. Technol. Educ., vol. 3, no. 1, pp. 35-39, 2009.

[11] K. Mustapa, "Efektivitas Pembelajaran Problem Posing dalam Meningkatkan Hasil Belajar dan Motivasi Mahasiswa Kimia Universitas Tadulako," Universitas Negeri Malang, 2009. 